\title{
Analýza daňového zat'aženia práce po zavedení tzv. rovnej dane
}

\author{
Anna Harumová*
}

\section{Úvod}

Medzi najvýraznejšie zmeny daňového systému v Slovenskej republike sa jednoznačne radia daňové reformy v roku 1993, v roku 1995 a posledná v roku 2004, kedy bola zavedená tzv. rovná daň. Základnými predpokladmi zavedenia rovnej dane bolo zdanit' všetky druhy ziskov a všetky výšky ziskov rovnako a takto docielit' maximálnu možnú spravodlivost', úplnú neutralitu, zjednodušenie a účinnost'.

\section{Ciele daňovej reformy}

Posledná daňová reforma sa uskutočňuje v kontexte d'alších spoločenských zmien, ako je napr. reforma sociálneho systému, dôchodkového zabezpečenia, zdravotníctva. Aby výsledný efekt bol optimálny a pozitívne pôsobil na hospodársky rast, rast pracovných príležitostí a neznižovali motiváciu k podnikaniu a k legálnemu zamestnávaniu je nevyhnutná koordinácia týchto reforiem a ich vzájomné zladenie.

Základom rozloženia daňového bremena $\mathrm{v}$ tejto daňovej reforme bolo presunutie daňového zat'aženia z priamych daní na dane nepriame (daň z pridanej hodnoty a spotrebné dane), ktoré sú z hl'adiska výberu daní jednoduchšie. Výsledkom daňovej reformy bolo zníženie váhy priamych daní, čo korešpondovalo s trendom uplatňovaným v Európe.

Medzi hlavné ciele poslednej daňovej reformy na Slovensku bolo nastolit' moderný daňový systém, ktorý by motivoval l'udí viac pracovat' a podnikatel'ov viac investovat', čím by sa vytvárali aj nové pracovné miesta. Uvedeným by mala daňová reforma prispiet' k dynamickému a udržatel’nému rastu ekonomiky a následne aj zvyšovaním rastu životnej úrovne obyvatel'ov. Táto daňová reforma bola koncipovaná na princípoch spravodlivosti, efektívnosti a jednoduchosti a predpokladá aj zníženie daňového zat’aženia práce.

\section{Daňové zat’aženie práce}

Významným ukazovatel'om popisujúcim daňové zat’aženie práce je priemerná efektívna sadzba dane z príjmu. Je to podiel odvedenej dane na hrubom príjme zamestnanca.

Analyzované boli dve kombinácie typu daňovníka: daňovník ako jednotlivec a daňovník $\mathrm{s}$ dvoma nezaopatrenými det'mi. V oboch prípadoch bol počítaný dopad v prípade poberania mzdy od 8000 Sk až po 50000 Sk mesačne. Pri výpočte efektívnych sadzieb je abstrahované od odvodového zat’aženia daňovníka a uplatnenia nezdanitel’ného minima na manželku.

Doc. Ing. Anna Harumová, PhD. - docentka; Katedra podnikových financií, Fakulta podnikového manažmentu, Ekonomická univerzita v Bratislave, Dolnozemská cesta 1, 85253 Bratislava 5; <harumova@dec.euba.sk>. 
Tab. 1: Výpočet efektívnej sadzby dane z príjmov - daňovník jednotlivec

\begin{tabular}{|c|r|r|r|r|c|}
\hline Príjem & $\begin{array}{c}\text { Na } \\
\text { daňovníka }\end{array}$ & $\begin{array}{c}\text { Daňový } \\
\text { bonus }\end{array}$ & Daň 19 \% & $\begin{array}{c}\text { Daň - daňový } \\
\text { bonus }\end{array}$ & $\begin{array}{c}\text { Efektívna } \\
\text { sadzba }\end{array}$ \\
\hline $8000,00 \mathrm{Sk}$ & $7328,00 \mathrm{Sk}$ & $0,00 \mathrm{Sk}$ & $128,00 \mathrm{Sk}$ & $128,00 \mathrm{Sk}$ & $1,60 \%$ \\
\hline $12000,00 \mathrm{Sk}$ & $7328,00 \mathrm{Sk}$ & $0,00 \mathrm{Sk}$ & $888,00 \mathrm{Sk}$ & $888,00 \mathrm{Sk}$ & $7,40 \%$ \\
\hline $17000,00 \mathrm{Sk}$ & $7328,00 \mathrm{Sk}$ & $0,00 \mathrm{Sk}$ & $1838,00 \mathrm{Sk}$ & $1838,00 \mathrm{Sk}$ & $10,81 \%$ \\
\hline $20000,00 \mathrm{Sk}$ & $7328,00 \mathrm{Sk}$ & $0,00 \mathrm{Sk}$ & $2408,00 \mathrm{Sk}$ & $2408,00 \mathrm{Sk}$ & $12,04 \%$ \\
\hline $30000,00 \mathrm{Sk}$ & $7328,00 \mathrm{Sk}$ & $0,00 \mathrm{Sk}$ & $4308,00 \mathrm{Sk}$ & $4308,00 \mathrm{Sk}$ & $14,36 \%$ \\
\hline $40000,00 \mathrm{Sk}$ & $7328,00 \mathrm{Sk}$ & $0,00 \mathrm{Sk}$ & $6208,00 \mathrm{Sk}$ & $6208,00 \mathrm{Sk}$ & $15,52 \%$ \\
\hline $50000,00 \mathrm{Sk}$ & $7328,00 \mathrm{Sk}$ & $0,00 \mathrm{Sk}$ & $8108,00 \mathrm{Sk}$ & $8108,00 \mathrm{Sk}$ & $16,22 \%$ \\
\hline
\end{tabular}

Tab. 2: Výpočet efektívnej sadzby dane z príjmov - daňovník s 2 nezaopatrenými det'mi

\begin{tabular}{|c|c|c|r|r|c|}
\hline Príjem & $\begin{array}{c}\text { Na } \\
\text { daňovníka }\end{array}$ & $\begin{array}{c}\text { Daňový } \\
\text { bonus }\end{array}$ & Daň 19 \% & $\begin{array}{c}\text { Daň - daňový } \\
\text { bonus }\end{array}$ & $\begin{array}{c}\text { Efektívna } \\
\text { sadzba }\end{array}$ \\
\hline $8000,00 \mathrm{Sk}$ & $7328,00 \mathrm{Sk}$ & $900,00 \mathrm{Sk}$ & $128,00 \mathrm{Sk}$ & $-772,00 \mathrm{Sk}$ & $-9,65 \%$ \\
\hline $12000,00 \mathrm{Sk}$ & $7328,00 \mathrm{Sk}$ & $900,00 \mathrm{Sk}$ & $888,00 \mathrm{Sk}$ & $-12,00 \mathrm{Sk}$ & $-0,10 \%$ \\
\hline $17000,00 \mathrm{Sk}$ & $7328,00 \mathrm{Sk}$ & $900,00 \mathrm{Sk}$ & $1838,00 \mathrm{Sk}$ & $938,00 \mathrm{Sk}$ & $5,52 \%$ \\
\hline $20000,00 \mathrm{Sk}$ & $7328,00 \mathrm{Sk}$ & $900,00 \mathrm{Sk}$ & $2408,00 \mathrm{Sk}$ & $1508,00 \mathrm{Sk}$ & $7,54 \%$ \\
\hline $30000,00 \mathrm{Sk}$ & $7328,00 \mathrm{Sk}$ & $900,00 \mathrm{Sk}$ & $4308,00 \mathrm{Sk}$ & $3408,00 \mathrm{Sk}$ & $11,36 \%$ \\
\hline $40000,00 \mathrm{Sk}$ & $7328,00 \mathrm{Sk}$ & $900,00 \mathrm{Sk}$ & $6208,00 \mathrm{Sk}$ & $5308,00 \mathrm{Sk}$ & $13,27 \%$ \\
\hline $50000,00 \mathrm{Sk}$ & $7328,00 \mathrm{Sk}$ & $900,00 \mathrm{Sk}$ & $8108,00 \mathrm{Sk}$ & $7208,00 \mathrm{Sk}$ & $14,42 \%$ \\
\hline
\end{tabular}

Ked' si pozrieme daňovníka s dvoma nezaopatrenými det'mi vzniká hlavne pri nižších príjmových skupinách situácia, kedy je efektívna sadzba od roku 2004 záporná. Zápornú efektívnu sadzbu môže vytvorit' daňový bonus. Pre porovnanie do roku 2003 sa znižoval základ dane o odpočítatel'nú položku na deti. V prípade, že základ dane bol menší alebo rovný nule, výsledná daň bola nulová a efektívna sadzba nemohla klesnút' do záporných hodnôt. Od roku 2004 je zavedený daňový bonus, ktorý sa odpočítava od výslednej dane. Daňovníkovi v nižšej príjmovej skupine môže vyjst' ročná daň v konečnom dôsledku nižšia ako je nárok na daňový bonus. V takejto situácii sa mu vrátia finančné prostriedky v hodnote rozdielu medzi daňou, ktorú má zaplatit' (zaplatil), a daňovým bonusom. Tu práve vzniká možnost’ zápornej efektívnej sadzby dane.

Celkovo možno konštatovat', že daňové zat'aženie na daňovníka sa po reforme výrazne znížilo, čím sa splnil jeden z ciel'ov daňovej reformy. Na tomto mieste je zaujímavý pohl'ad aj na progresivitu zdanenia. Pre vyššie uvedené typy daňovníkov (jednotlivec a rodina s dvoma det'mi) pri danom príjmovom rozpätí (od 8000 Sk do 50000 Sk mesačne) efektívna daň z príjmu (daň/hrubá mzda) bola pred reformou v rozpätí od $0 \%$ do $22 \%$ a po reforme $\mathrm{v}$ rozpätí od $-12 \%$ do $+16 \%$. Inak povedané, progresivita dane pred reformou bola v pásme $22 \%$ z hrubej mzdy, po reforme je to až $28 \%$ z hrubej mzdy vd'aka bonusu na diet'a. V rozpore s tým, ako bola rovná daň od začiatku na Slovensku vnímaná, táto daň teda pri určitých typoch daňovníkov progresivitu skutočne znížila, pri iných však zvýšila (Krajčír Ódor, 2005). 
Rovná daň si stále zachováva progresívnu povahu efektívnych sadzieb dane, ktorú platia jednotlivci s rôznou výškou príjmov. Príjmy fyzických osôb do výšky 1,6 násobku hranice chudoby budú oslobodené od dane. V dôsledku toho efektívna sadzba dane pre jednotlivcov pod týmto prahom bude nulová. Priemerná sadzba dane začne narastat' v momente, ked' jednotlivec prekročí tento prah. Zavedenie rovnej dane z príjmov nemá negatívny dopad na osoby s nízkym príjmom, iba zanedbatel'ný dopad $\mathrm{v}$ strednom rozpätí výšky príjmov a pozitívny dopad na osoby s najvyššími príjmami. Existencia jednej marginálnej daňovej sadzby pre všetky príjmy vyššie ako je príjem pre štandardné oslobodenie od dane, znižuje deformačné účinky zdaňovania príjmov fyzických osôb a obmedzuje ekonomické prekážky $\mathrm{s}$ tým spojené. To by malo zvýšit' produktivitu práce $\mathrm{v}$ krátkodobom aj dlhodobom horizonte, pretože stimuluje $\mathrm{k}$ vyšším pracovným výkonom, ako aj vyššie investície do l'udského kapitálu (Finance.sk, 2007).

\section{Marginálne efektívne daňové sadzby}

Marginálna efektívna daňová sadzba vyjadruje kol'ko zoberie štát daňovníkovi z dodatočne zarobenej hrubej mzdy. Oplatí sa teda daňovníkovi vyvíjat' dodatočné úsilie na zvýšenie svojej hrubej mzdy?

Pre problematiku trhu práce je dôležité ako vplýva daňové a odvodové zat'aženie na rozhodovanie jednotlivca. Rozhodovanie je založené na porovnávaní nárastu resp. poklesu čistého príjmu pri zvýšení či znížení ponuky práce. Za zvyšovanie svojho príjmu však zamestnanec (patriaci do nízkopríjmovej skupiny) neplatí len zvýšením odvodov daní a príspevkov na sociálne a zdravotné poistenie, ale tiež znížením sociálnych dávok, ktorých výška je odvádzaná od vel'kosti príjmu. Efekt zvyšovania daní a znižovania sociálnych dávok sa môže prejavit' vo vysokom marginálnom efektívnom zdanení. V niektorých prípadoch, pri nedostatočnom zladení systému sociálnych dávok a daní, môže hodnota hraničných efektívnych daňových sadzieb prekročit' i 100 \%. To znamená, že nárast hrubých pracovných príjmov z dôvodu zvýšenia pracovnej činnosti alebo prechodu na lepšie platenú prácu bude sprevádzané nulovým alebo len miernym zvýšením čistých príjmov. V odbornej literatúre Haveman (1996) - je však považovaná za demotivujúcu i hodnota $M E T R(E P)$ prevyšujúca $50 \%$ a za vyhovujúce sa považujú hodnoty pohybujúce sa maximálne v intervalu 30 až $50 \%$.

Hraničné efektívne daňové sadzby sa teda odrádzajú od zvyšovania pracovného úsilia a teda obmedzujú flexibilitu trhu práce.

Hraničná efektívna daňová sadzba pre zamestnané osoby (marginal effective tax rate for employed persons - METR(EP)), udáva, o kol'ko sa zvýšia zaplatené dane a znížia sociálne dávky, ak sa hrubý pracovný príjem zvýši o jednotku. Daný ukazovatel' je definovaný ako jedna mínus pomer zmeny čistého príjmu ku zmene hrubého príjmu:

$$
\operatorname{METR}(E P)=I-\frac{\Delta N E I}{\Delta G E I},
$$

kde $\operatorname{METR}(E P)$ = hraničná efektívna daňová sadzba pre zamestnané osoby,

$\triangle N E I=$ zmena čistého príjmu,

$\triangle G E I=$ zmena hrubého príjmu.

Zmena čistého príjmu je definovaná ako funkcia zmeny hrubého príjmu (z práce), hraničnej daňovej sadzby vrátane príspevkov na sociálne a zdravotné poistenie platené zamestnancom a sadzby znižujúcej hodnotu sociálnych dávok. Miera redukcie sociálnych 
dávok dosahuje $100 \% \mathrm{v}$ prípade, že sú tieto dávky redukované o rovnakú čiastku, o ktorú narástol pracovný príjem po zdanení. Táto situácia je typická pre systémy, kde sú sociálne dávky konštruované ako rozdiel medzi príjmom po zdanení a životným minimom.

Vo výpočtoch efektívnej hraničnej daňovej sadzby sme sa zamerali na zvýšenie mzdy pohybujúcej sa okolo minima a mzdy oscilujúcej okolo priemeru. Tabul'ka ukazuje výpočet marginálnej efektívnej daňovej sadzby daňovníka jednotlivca pred a po reforme.

Tab. 3: Výpočet marginálnej efektívnej sadzby dane z príjmov - daňovník jednotlivec

\begin{tabular}{|l|c|c|c|c|c|c|}
\hline Rok & $\mathbf{2 0 0 3}$ & $\mathbf{2 0 0 3}$ & Zmena & $\mathbf{2 0 0 3}$ & $\mathbf{2 0 0 3}$ & Zmena \\
\hline Hrubý príjem & $7000 \mathrm{Sk}$ & $8500 \mathrm{Sk}$ & $1500 \mathrm{Sk}$ & $16000 \mathrm{Sk}$ & $20000 \mathrm{Sk}$ & $4000 \mathrm{Sk}$ \\
\hline Čistý príjem & $5817 \mathrm{Sk}$ & $6994 \mathrm{Sk}$ & $1177 \mathrm{Sk}$ & $12558 \mathrm{Sk}$ & $15348 \mathrm{Sk}$ & $2790 \mathrm{Sk}$ \\
\hline Marginálna sadzba & & & $21,5 \%$ & & & $30,3 \%$ \\
\hline
\end{tabular}

\begin{tabular}{|l|c|c|c|c|c|c|}
\hline Rok & $\mathbf{2 0 0 5}$ & $\mathbf{2 0 0 5}$ & Zmena & $\mathbf{2 0 0 5}$ & $\mathbf{2 0 0 5}$ & Zmena \\
\hline Hrubý príjem & $7000 \mathrm{Sk}$ & $8500 \mathrm{Sk}$ & $1500 \mathrm{Sk}$ & $16000 \mathrm{Sk}$ & $20000 \mathrm{Sk}$ & $4000 \mathrm{Sk}$ \\
\hline Čistý príjem & $6062 \mathrm{Sk}$ & $7355 \mathrm{Sk}$ & $1293 \mathrm{Sk}$ & $12616 \mathrm{Sk}$ & $15422 \mathrm{Sk}$ & $2806 \mathrm{Sk}$ \\
\hline Marginálna sadzba & & & $13,8 \%$ & & & $29,9 \%$ \\
\hline
\end{tabular}

Pri porovnaní dvoch sledovaných období vidíme hlavne pokles marginálnej sadby pri zvýšení príjmu nízkopríjmových skupín. V roku 2005 predstavuje marginálna sadzba iba $13,8 \%$. To znamená, že z dodatočne zarobenej koruny musíme odviest' štátu približne 14 halierov, čo je o 7,5 haliera menej ako v roku 2003.V absolútnom vyjadrení ide o zvýšenie čistého príjmu o 116 Sk (1 293 -1 177) oproti roku 2003. Pri zvýšení priemerných miezd je v obidvoch sledovaných obdobiach marginálna sadba približne rovnaká. Nový daňový systém podporuje a motivuje zvyšovat' pracovný výkon hlavne nízkopríjmové skupiny.

Výpočet marginálnej sadzby môže byt' rozložený aj na hraničné sadzby jednotlivých príjmových alebo odvodových komponentov. Pre zložitost' výpočtu udávame iba metodický postup výpočtu:

$$
\operatorname{METR}(E P)=\frac{\Delta I T+\Delta S S C_{E E}-\Delta H B-\Delta F B-\Delta S B-\Delta S A}{\Delta G E I},
$$

kde $I T=$ daň z príjmov fyzických osôb,

$S S C_{E E}=$ príspevky na sociálne a zdravotné poistenie platené zamestnancom,

$H B=$ príspevok na bývanie,

$F B=$ prídavky na deti,

$S B=$ sociálny príplatok,

$S A \quad=$ dávky z titulu sociálnej potreby,

GEI = hrubá mzda.

Vplyv jednotlivých komponentov na vel'kost' $M E T R(E P)$ možno d'alej rozpísat' (príklad pre príspevok na bývanie):

$$
\frac{\Delta H B}{\Delta G E I}=\frac{\Delta H B}{H B} \cdot \frac{H B}{G E I} \cdot \frac{G E I}{\Delta G E I},
$$


kde prínos každej zložky k $M E T R(E P)$ je výsledkom nielen jej percentuálnej zmeny, ale tiež jej významu meraného pomerom $\mathrm{k}$ hrubej mzde.

Výsledná hodnota $\operatorname{METR}(E P)$ udáva, kol'ko percent efektívne odvedie daňovník (popr. kol'ko odvedie na daniach a o kol'ko sa mu zníži príjem zo sociálnych dávok), ak sa jeho hrubý príjem zvýši o jednotku (v empirickej časti sa počíta so zmenou v hrubom príjme o $1 \%$ priemernej mzdy). V prípade, že hodnota $\operatorname{METR}(E P)$ presiahne $100 \%$, znamená to, že sa zvýšenie hrubého príjmu premietne $\mathrm{v}$ znížení čistého príjmu. $\mathrm{V}$ takomto prípade by bolo iracionálne zvyšovat' ponuku práce a daňovník sa dostane do pasce chudoby (Ódor, 2005).

S problematikou nízkej motivácie ku zvyšovaniu pracovného úsilia za zaoberá mnoho členských štátov a odstránenie tohto problému je dôvodom reforiem. Reformu uskutočnenú na Slovensku, možno považovat' z hl'adiska hodnôt sledovaného ukazovatel'a $\operatorname{METR}(E P)$ ako jednu z najúspešnejších..

Podstatný zásah do štruktúry hraničných efektívnych daňových sadzieb predstavovala reforma daňového a sociálneho systému, ktorá vstúpila v platnost' 1. januára 2004. Hlavné opatrenia, ktoré boli uskutočnené sú:

- zavedenie dane z príjmov fyzických osôb s jednotnou sadzbou vo výške 19 \%;

- viazanie vel'kosti odpočítatel'ných položiek u dane z príjmov fyzických osôb na hodnotu životného minima;

- zámena odpočítatel'nej čiastky na diet'a za daňový bonus;

- starostlivost' o nezaopatrené diet’a umožňujúca znížit' sadzbu poistného na sociálne zabezpečení;

- zavedenie plošných prídavkov na deti;

- zavedenie maximálnej hranice pre dávky z titulu sociálnej núdze;

- započítavanie iba časti príjmu z práce do rozhodného príjmu pre priznávanie dávok z titulu sociálnej núdze.

Výsledkom uvedených zmien je podstatná zmena v hodnotách hraničných efektívnych daňových sadzbách. Vo všetkých prípadoch testovaných typov domácností bolo zaznamenané výrazné zlepšenie najmä $\mathrm{v}$ prípade nízkopríjmových pracovníkov, kde bola znížená najproblémovejšia hodnota sadzby $\operatorname{METR}(E P)$ zo $100 \%$ na $77 \%$ (rast hrubej mzdy bol sprevádzaný znížením sociálnym dávok). D̉alej sa znížilo hraničné zdanenie l'udí s vyššími príjmami a bol odstránený najviac distorzný prvok - testované prídavky na deti vyplácané v paušálnej vel'kosti. Vd'aka tomu sa už nestretávame so situáciou, ked' hodnoty $\operatorname{METR}(E P)$ presahujú $100 \%$. Negatívom uskutočnenej reformy však je, že došlo $k$ presunu demotivačných hodnôt viac smerom k priemernej mzde. Systém sa tak stal menej motivačný pre stredne príjmové skupiny.

\section{Záver}

Zavedenie rovnej dane v SR spôsobuje vyššiu alokáciu príjmov do štátneho rozpočtu, znižuje mieru prerozdelenia príjmov v spoločnosti a z dlhodobého hl'adiska stimuluje ekonomický rast a tvorbu investícií. $Z$ pohl'adu jednotlivcov a podnikov ruší progresívne zdanenie, ktoré doteraz postihovalo hlavne úspešnejších, teda s vyššími príjmami. Na druhej strane zavedenie rovnej dane zvýhodňuje túto skupinu a znevýhodňuje skupinu jednotlivcov a podnikov s nižšími príjmami. Systém sa tak stal menej motivačný pre stredne príjmové skupiny (srv. Harumová, 2006, Harumová - Kubátová, 2006). 


\section{Literatúra}

[1] Finance.sk (2007): Dan z príjmov. [on-line], Bratislava, AWD, c2000-2007, [cit. 30. 9. 2007], <www.finance.sk/danovnictvo/prehlad/prijem>.

[2] Harumová, A. (2006): Zavedenie rovnej dane a jej vplyv na daňové príjmy štátu. In: Teoretické a praktické aspekty veřejných financí. Praha, Oeconomica, 2006, s. 16.

[3] Harumová, A - Kubátová, K. (2006): Dane podnikatel'ských subjektov. Žilina, Poradca, 2006.

[4] Haveman, R. (1996): Reducing Poverty While Increasing Employment: A Primer on Alternative Strategies and a Blueprint. [on-line], Paris, OECD Economic Studies, 1996, roč. 26, č. 1, [cit. 30. 9. 2007], <http://www.oecd.org/dataoecd/60/6/2502824.pdf>.

[5] Krajčír, Z. - Ódor, L. (2005): Prvý rok daňovej reformy alebo 19 \% v akcii. [on-line], Bratislava, Inštitút finančnej politiky Ministerstvo financií SR, c2005, [cit. 30. 9. 2007], $<$ http://www.finance.gov.sk/documents/ifp/publikacie/fiskal/ea8_tax_reform.pdf $>$.

[6] Ódor, L. (2005): Možnosti znižovania odvodov na Slovensku. [on-line], Bratislava, Inštitút finančnej politiky Ministerstvo financií SR, c2005, [cit. 30. 9. 2007], $<$ http://www.finance.gov.sk/documents/ifp/publikacie/fiskal/ea_7_odvody.pdf $>$. 


\title{
Analýza daňového zat’aženia práce po zavedení tzv. rovnej dane
}

\author{
Anna Harumová
}

\begin{abstract}
ABSTRAKT
Zavedenie rovnej dane v SR spôsobuje vyššiu alokáciu príjmov do štátneho rozpočtu, znižuje mieru prerozdelenia príjmov v spoločnosti a z dlhodobého hladiska stimuluje ekonomický rast a tvorbu investícíi. $Z$ pohl'adu jednotlivcov a podnikov ruší progresívne zdanenie, ktoré doteraz postihovalo hlavne úspešnejších, teda s vyššími príjmami. Na druhej strane zavedenie rovnej dane zvýhodňuje túto skupinu a znevýhodňuje skupinu jednotlivcov a podnikov s nižšími príjmami. Systém sa tak stal menej motivačný pre stredne príjmové skupiny

Klíčová slova: Daň; Rovná daň; Daňové aspekty; Motivácia; Stimulácia ekonomického rozvoja.

\section{Analysis Tax Work Charging after Implementation So-called Equal Tax}

ABSTRACT

Application equal tax in the Slovak Republic makes better allocation of income to the state budget, reduce rate repartionings in society and from long-time aspect is stimulating economic expand and creation of investments. From individual and companies view cancel progressive taxations, which up to now relate mainly enjoy success, then with higher income society. On the second side equal tax implementation advantage this category and don't advantage category of individual and companies with low income. The system became less motivating for middle income groups.
\end{abstract}

Key words: Tax; Equal tax; Taxes aspects; Motivating; Stimulating economic expand.

JEL classification: $\mathrm{H} 2$. 